\title{
Cultural Values and Leadership Excellence
}

\author{
Pieter Sahertian*, Umiati Jawas \\ Universitas PGRI Kanjuruhan Malang \\ Malang, Indonesia \\ *pieter@unikama.ac.id, umiati_jawas@unikama.ac.id
}

\begin{abstract}
The study of leadership from a cultural perspective has not been widely discussed, especially for the case in Indonesia. Meanwhile, organizations in Indonesia employ employees including leaders who come from various cultural and ethnic backgrounds. This study aims to describe the influence of cultural values on the formation of leadership excellence in organizations. GSCA analysis is used to test the structural model, while Confirmatory Factor analysis is used to examine the factor structure of the leadership excellence scale. Respondents were involved in this study who were taken by purposive sampling technique. The results showed that the dimensions of Managerial Behavior, Environmental Influence, Organizational Demand and Personal Qualities were all related to the construction of Excellent Leader. Another important point of this research is that the cultural values inherent in leaders influence their leadership behavior to form leadership excellence in the organization.
\end{abstract}

Keywords-cultural values, leadership formation, leadership excellence, organization leaders

\section{INTRODUCTION}

Leadership is the ability to influence others to achieve common goals. The facts show that leadership exists in all organizations in countries with different cultures. But what distinguishes one from another is its effectiveness. The differences can be explained because of the differences in cultural values they have. Leadership style and other social behaviour are influenced by the cultural dimension in which the behaviour occurs. Most of the leadership attributes are determined based on the values inherent in the leader as a person. Of course, culture is not the only determinant of leadership behaviour. There are so many organizations that build their culture by adopting cultural values that are brought by individuals into their workplaces and practicing them when interacting communally. Each individual has their own personality, which they use in all social situations and environments large and small.

There are many approaches and traits of leadership research that are constantly changing. This research is based on the Excellence in Leadership scale including: Organizational Demand, Personal Qualities, Managerial Behaviour and Environmental Influence [1]. Therefore, the four dimensions used in defining leadership excellence in this study have the potential to provide cultural insights into leadership values.
Several researchers have conducted effects of cultural values in relation to leadership excellence. Selvarajah and Meyer [2] used a Malaysian cultural background, Anurit [3] with a Thai cultural background and Selvarajah, Mejer and Davuth [4] with a Cambodian cultural background

This study uses the cultural and ethnic backgrounds of leaders who come from various regions in Indonesia who have different characteristics from one another. Are the dimensions of leadership excellence and their relationship with values in the perspective of local wisdom in the formation of leadership excellence as experienced by leaders in several ASEAN countries also experienced by leaders in Indonesia? This research question will be explained in this article.

\section{A. Leadership and Culture}

Not many empirical or conceptual (theoretical) studies have been conducted regarding the relationship between culture and leadership. A number of studies that include cultural contextualization have been carried out in various countries [510]. In another study, it was explained that cultural contextualization is considered important where culture always colours every aspect of human behaviour, and therefore knowledge of culture and its effects is useful for leaders who work in a cross-cultural organizational environment [11].

Most studies related to the national aspect, do not seriously look at the sub-population of the country as contributors to leadership values. Kennedy [6] reported in a GLOBE study in Malaysia entitled, "Leadership in Malaysia", misinterpreted the values of indigenous Malaysians as a surrogate measure for the values of managers there, thus ignoring the role and contribution of Chinese and Indians to leadership in Malaysia. In many countries in Southeast Asia, certain ethnic groups have great power, and this affects the perception of the value of leadership [2].

On the other hand, the research of Karande et al. [5] aimed to examine the cross-cultural moral philosophies of marketing managers in the United States, Australia and Malaysia, but the results of the study failed to explain the effects of subcultures in their analysis. Anurit [3] explains that there are so many studies that emphasize the national dimension, and do not take advantage of the population of various regions in the country to construct local wisdom-based values as forming leadership values for leaders. 
In the organizational structure in Indonesia, there are so many leaders who come from various ethnic and cultural backgrounds. In both private and government organizations, we can find leaders who come from various regions with different ethnic and cultural backgrounds in Indonesia. Leaders with ethnic, Chinese, Arab and Indian ethnicities can be found at the top manager level to the lower manager level. Swierczek [12] argues that there are three major streams of leadership styles in Asia, which can be distinguished in cultural backgrounds. These are all styles of East Asia (Japan, China and Korea), South Asia (India, Nepal, Pakistan and Srilanka) and Southeast Asia (Indonesia, Malaysia, Singapore, Thailand etc.). In Indonesia, there are other styles of leadership that originate from the West Asia region or what is known as the Middle East. Aldulaimi [13] explains that consultation is a value and attitude of Arab leaders in the decision-making process, where one must consult with more experienced people. Like other Asian countries, Arab countries, although culturally the same, differ in their preferences and dominant values due to colonialism.

\section{B. Leadership Excellence}

Leadership excellence development models have been studied by both western and eastern authors and researchers as identified by Taormina and Selvarajah [14] in Selvarajah et al. [1]. Various western literatures such as [15-19], as well as eastern ones [20-23] have been widely quoted. Anurit [3] found that strong cultural factors such as non-confrontation and mutual respect can moderate the perception of Thai managers about an excellent leader. Selvarajah, Mejer and Devauth's [24] research on leadership excellence and culture in Cambodia shows the importance of the cultural context when considering leadership behaviour. In Cambodia, the influence of religion and past history is of interest in understanding leadership and managerialism and their implications for management and theoretical development. Likewise, the research results of Selvarajah and Meyer [2], found that of the three ethnic groups (Malaysian, Chinese and Indians) who participated in their research, it was stated that Malaysian managers maintain distinctive leadership behaviours based on their respective ethnicities and identities in lead. As a country, different ethnic populations are still unable to place a single Malaysian identity.

\section{METHODS}

The unit of analysis in this study was the leaders from various regions with different ethnic and cultural backgrounds. The data to be analysed from the sample were obtained by using a purposive technique. The Excellent Leader measurement scale includes Personal Qualities, Managerial Behaviour, Organizational Demands and Environmental Influences developed by Selvajarah et al. [1]. GSCA analysis is used to measure the overall model. Confirmatory Factor Analysis is used to examine the factor structure of the scale. SPSS v18 was used for data analysis in this study.

\section{RESULTS AND DISCUSSION}

The loading factor value shows that the indicators of each dimension have significant differences. Indicators of economic use for planning purposes on the Environmental Influences dimension, focusing on tasks carried out on the Managerial Behaviour dimension, giving priority to Long-term goals on the Organizational Demands dimension, and treating employees as trusted and honest people on the Personal Qualities dimension, are the most dominant indicators in describing leader excellence variable.

The results of GCSA analysis show that the dimensions of Environmental Influences and Personal Qualities have a positive and significant relationship to the leadership excellence variable, because the critical value obtained is significant at the $95 \%$ confidence level so that both dimensions are suitable for measuring leadership excellence. While the Managerial Behaviour and Organizational Demands dimensions have a positive relationship to the leadership excellence variable, but the relationship is meaningless because the critical value obtained is not significant at the $95 \%$ confidence level, so both are not suitable dimensions to measure leadership excellence. The results show that what Selvarajah and Meyer [2] describe to managers in Malaysia is not fully supported by the results of this study.

The results of the analysis show that the ability to use economic indicators for planning purposes (Environmental Influences), focus on tasks being carried out (Managerial Behaviour), give priority to long-term goals (Organizational Demands), treat employees as trusted and honest people (Personal Qualities), are the most dominant indicators. In describing the dimensions of leadership excellence. The loading factor value has shown that the indicators of each dimension measured in general are able to explain the construct of leadership excellence, although there are certain indicators that are more dominant in describing the dimension of leadership excellence.

The results of the GSCA analysis show that the dimensions of Environment Influence, Managerial Behaviour and Organizational Demand have a significant relationship. This implies that these three dimensions are very suitable for measuring the leadership excellence of an organizational leader. Meanwhile, Personal Qualities have a positive but meaningless relationship. Thus, these two dimensions are not suitable factors to measure the criteria for leadership excellence dimensions. These results found that the cultural values inherent in leaders influenced their leadership behaviour to form leadership excellence in their organization.

The results of this study support Selvarajah and Meyer's [2] research which explains that the Management Behaviour and Organizational Demand are important dimensions in explaining the criteria for an excellence leader in Malaysia. This study is also in line with the thought of Mencius in Selvarajah [25] who suggested that Chinese managers consider Managerial Behaviour variables more. This study also corroborates Sinha's [26] description of effective leadership styles in the Indian 
context which explains that the Organizational Demand dimension is the most important dimension for Indian managers.

The factors that shape the behaviour of leaders, their personalities, the demands of the organization and the environment that are important should be considered in the context of performance. Leaders come from different ethnic backgrounds, traditions, histories and social systems and are shaped by many religious values. The feeling of togetherness which is family oriented must be integrated into an organization. Good leaders demand loyalty and trust and ensure that the needs of their workers can be met [27]. In particular, the factors that make up the dimensions of Organizational Demand and Personal Qualities need to be recognized and appreciated. Leaders also need to realize that the motivation behind employees dedicating their full potential is to some extent inspired by the cultural values and local wisdom inherent in everyone.

The important thing that needs to be underlined from this research is that historical, social, and cultural factors contribute to the way management is carried out in organizations. The culture that lives and develops in Indonesia has contributed and even dominated the behaviour of business and social activities for centuries in a long period of influence on the practice and policies in every organization. It cannot be denied that colonial influences such as social, economic and political structures, together with layers of religious influence, provide the background for understanding the socio-cultural aspects of Indonesia. It is in this context that leadership should be understood in a multicultural country like Indonesia. Understanding Indonesia's ethnic communities will provide a basis for understanding leadership excellence in Indonesia organizations.

\section{CONCLUSION}

This study describes the contribution of cultural values to the behaviour of leaders which is more closely related to ethnicity. Empirically, the results of the research show that the data in the field are in line with previous studies. This study found that the dimensions of Managerial Behaviour, Environmental Influence, Organizational Demand and Personal Qualities were all related to the construction of Excellent Leader. Additionally, the important highlight of this research is that the cultural values inherent in leaders influence their leadership behaviour to form leadership excellence in the organization. This explains that to become an excellent leader, cultural values can contribute to the behaviour of the leader. Because cultural values are part of a value system that helps shape people's behaviour; therefore, it must be considered that organizations need to include cultural values to become part of the organizational culture.

\section{ACKNOWLEDGMENT}

This article publication in ANCOSH 2020 proceeding is supported by the research grant funded by The Directorate of
Higher Education Ministry of Research and Technology Republic of Indonesia with the decree number: 039/SP2H/LT/MONO/L7/2019.

\section{REFERENCES}

[1] C. Selvarajah, P. Duignan, C. Nuttman, and C. Suppiah, "In search of the Asian leader: an exploratory study of dimension that relates to excellence in leadership," Management International Review: Journal of International Business, vol. 35, no. 1, pp. 29-34, 1995.

[2] C. Selvarajah and D. Meyer, "One Nation, three cultures: exploring dimensions that relate to leadership in Malaysia," Leadership \& Organization Development Journal, vol. 28, no. 8, pp. 693-712, 2008

[3] P.J. Anurit, "Key dimension that are relevant to leadership excellence in Thailand," International Journal of Business and Commerce, vol. 1, no. 9, pp.79-106, 2012.

[4] C. Selvarajah, M. Denny, and Dy Davuth, "The effect of cultural modelling on leadership profiling of the Cambodian manager," Asia Pasific Business Review, vol. 18, no. 4, pp. 649-674, 2012

[5] K. Karande, C.P. Rao, and Singhakpadi, "Moral philosophies of managers: a comparison of American, Australian, and Indonesian cultures," European Journal of Marketing, vol. 36, no. 7/8, pp. 768-91, 2002.

[6] J.C, Kennedy, "Leadership in Indonesia: traditional values, internationa outloo," Academy of Management Excecutive, vol. 16, no. 3, pp. 15-25, 2002.

[7] R.A. Saufi, S.A. Wafa, and M.Y.Z. Hamzah, "Leadership style prefernces of Indonesian managers," Indonesian Management Review, vol. 37, no. 1, pp. 1-10, 2002.

[8] L. Lim, "Work-related values of Malays and Chinese Malaysians," International Journal of Cross Cultural Management, vol. 1, no. 2, pp. 229-246, 2001.

[9] J.L. Gupta and M. Sulaiman, "Ethical Orientation of Managers in Indonesia," Journal of Business Ethics, vol. 15, pp. 735-48, 1994

[10] G.H. Hofstede, "Managing in multicultural society," Culture's, Malaysian Management Review, vol. 26, no. 1, pp. 10-19, 1991.

[11] M. Javidan, P.W. Dorfman, M.S. de Luque, and R.J. House, "In the eye of the beholder: Cross culture lessons in leadership from project Globe," Academy of Management Perspectives, vol. 20, no. 1, pp. 68-90, 2006.

[12] F.W. Swierczek, "Leadership and culture: Comparing Asian manager," Leadership and Organization Development Journal, vol. 12, no. 7, pp. 3 10, 1991.

[13] S.H. Aldulaimi, "Leadership Concept and Constructs in Arabic Philosophy," Journal of Economic Cooperation and Development, vol. 40, no. 2, pp. 193-210, 2019.

[14] R. Taormina and C. Selvarajah, "Perception of leadership excellence in ASEAN nations," Leadership, vol. 1, no. 3, pp. 299-322. 2005.

[15] T. Takala, "Plato on leadership," Journal of Business Ethic, vol. 17, pp. 785-797, 1998.

[16] W.G. Bennis, On becoming a leader. Reading, MA: Addison-Wesley, 1989.

[17] G.A. Yukl, Leadershi in Organization, 2nd ed. Cliffs, NJ: Prentice Hall, Englewood, 1989

[18] B. Bass, Leadership and Performance Beyond Expectation. New York, NY: Free Press, 1998

[19] T.J. Peters and R.H. Waterman, In search of excellence: Lessons from America's bestrun companies. New York: Harper and Row, 1983.

[20] W. Ling, L. Fang, J. Gao, and A. Khanna, "The effect of different social groups on implicit leadership factors," Acta Psychologica Sinica, vol. 2 no. 1, pp. 43-49 [In Chinese], 1992.

[21] W. Ling, "Pattern of leadership behavior assesment in China," Psychologia: An International Journal of Psychology in The Orient,vol. 32 , no. 2, pp. $129-134,1989$ 
[22] L.C. Xu, L. Chen, D. Wang, and A.Y. Xue, "The role of psychology in enterprise management," Acta psychologica sinica, vol. 1, no. 4, pp. 339-345 [In Chinese], 1985.

[23] J. Misumi, The Behavioural Science of Leadership. Tokyo: Yuhikaka, 1984.

[24] C. Selvarajah, M. Denny, and Dy Davuth, "The effect of cultural modelling on leadership profiling of the Cambodian manager," Asia Pasific Business Review, vol. 18, no. 4, pp. 649-674, 2012.
[25] C. Selvarajah, "Cultural diversity management in Malaysia: Astudy of Indian, Chinese and Malay business leadership,” In: K.J.R. Amar Nayak and M.C. Jomon eds. India in the emerging global order. New Delhi: Taj McGraw Hill, 2008, pp. 267-282.

[26] J.B.P. Sinha, The cultural context of leadership and power. New Delhi: Sage Publication, 1995.

[27] D. Goleman, Working with emotional intelligence. New York, NY: Bantam Doubleday, 2000 